\title{
Ongoing, but slowing, habitat loss in a rural landscape over 85 years
}

\author{
Lucy E. Ridding (1) - Stephen C. L. Watson • Adrian C. Newton • \\ Clare S. Rowland · James M. Bullock
}

Received: 9 July 2019/Accepted: 25 November 2019/Published online: 4 December 2019

(C) The Author(s) 2019

\begin{abstract}
Context Studies evaluating biodiversity loss and altered ecosystem services have tended to examine changes over the last few decades, despite the fact that land use change and its negative impacts have been occurring over a much longer period. Examining past land use change, particularly over the long-term and multiple time periods, is essential for understanding how rates and drivers of change have varied historically.

Objectives To quantify and assess patterns of change in semi-natural habitats across a rural landscape at five time points between 1930 and 2015.
\end{abstract}

Electronic supplementary material The online version of this article (https://doi.org/10.1007/s10980-019-00944-2) contains supplementary material, which is available to authorized users.

L. E. Ridding $(\bowtie) \cdot$ J. M. Bullock

UK Centre for Ecology \& Hydrology, Maclean Building, Benson Lane, Crowmarsh Gifford, Wallingford,

Oxfordshire OX10 8BB, UK

e-mail: lucridd@ceh.ac.uk

S. C. L. Watson - A. C. Newton

Faculty of Science and Technology, Centre for Ecology, Environment and Sustainability, Bournemouth University, Talbot Campus, Poole, Dorset BH12 5BB, UK

C. S. Rowland

UK Centre for Ecology \& Hydrology, Library Avenue, Lancaster LA1 4AP, UK
Methods We determined the habitat cover at over 3700 sites across the county of Dorset, southern England in 1930, 1950, 1980, 1990 and 2015, using historical vegetation surveys, re-surveys, historical maps and other contemporary spatial data.

Results Considerable declines in semi-natural habitats occurred across the Dorset landscape between 1930 and 2015. This trend was non-linear for the majority of semi-natural habitats, with the greatest losses occurring between 1950 and 1980. This period coincides with the largest gains to arable and improved grassland, reflecting agricultural expansion after the Second World War. Although the loss of semi-natural habitats declined after this period, largely because there were very few sites left to convert, there were still a number of habitats lost within the last 25 years. Conclusions The findings illustrate a long history of habitat loss in the UK, and are important for planning landscape management and ameliorative actions, such as restoration. Our analysis also highlights the role of statutory protection in retaining semi-natural habitats, suggesting the need for continued protection of important habitats.

Keywords Afforestation - Agricultural intensification $\cdot$ Habitat loss $\cdot$ Land cover $\cdot$ Seminatural habitat $\cdot$ Urbanisation 


\section{Introduction}

Land use change is one of the main ongoing drivers of terrestrial biodiversity loss and the alteration of ecosystem functions and services (Bateman et al. 2013; Tittensor et al. 2014). Many studies evaluating biodiversity loss and altered ecosystem services have tended to examine changes over the last few decades (van Swaay et al. 2013; Renard et al. 2015; Hallmann et al. 2017; Song et al. 2018; Van der Sluis et al. 2019), despite the fact that land use change and its negative impacts have been occurring over a much longer period in Europe (Hooftman and Bullock 2012), Asia (Dearing et al. 2012) and America (Drummond et al. 2017). Examining past land use change is essential for understanding the full extent of loss and altered functions, predicting future changes, and planning potential response actions, such as ecological restoration.

Semi-natural habitats have high conservation importance in many parts of the world. Semi-natural habitats are those which were created by traditional human activities and are maintained by management, such as grazing, coppicing, cutting or burning (Poschlod and Wallis de Vries 2002). In western Europe these habitats include unimproved grasslands, heathland and broadleaved woodland. Such sites often support a high diversity of species, some of which are of conservation concern (Webb et al. 2010). Seminatural habitats are also important for the delivery of ecosystem services including pollination, timber production, carbon storage and aesthetic value (Quine et al. 2011; Cordingley et al. 2015; Bengtsson et al. 2019). However, there has been a significant decline in many semi-natural habitats across Europe in the last century. For example, lowland heathland in Europe previously extended over several million hectares, with only an estimated 350,000 hectares now remaining (Diemont et al. 1996). Similarly, in England and Wales, an estimated $97 \%$ of semi-natural grassland was lost between 1932 and 1984 (Fuller 1987). The decline in semi-natural habitats over the past few decades is often treated as linear; but this has not been directly quantified in the UK. Furthermore, trends are presumed to be common across all semi-natural habitat types (Hooftman and Bullock 2012), though very few studies have examined the potential differences across landscapes.
In considering change in semi-natural habitats over time, whilst a linear decrease might be assumed, changes could accelerate or decelerate over time, or show more idiosyncratic patterns (Bürgi et al. 2004). Knowledge of how trends have changed in the recent past is at the core of biodiversity reporting, both nationally (DEFRA 2018) and internationally (Secretariat of the Convention on Biological Diversity 2014), but little is known about patterns over long timescales. Such information would show whether loss is slowing or increasing and even if there have been gains at any point. Trends across different habitat types could be assessed and drivers identified at different time points. Furthermore, understanding patterns of change and how drivers of decline vary in importance can be used to predict future changes, reduce ongoing habitat loss and identify where restoration could be targeted. A number of studies have assessed loss for particular habitat types over long time periods. For example, the status of the heathlands in the county of Dorset, England has been assessed since the 19th century (Moore 1962; Rose et al. 2000). Others have examined multiple habitats or land-use change using two snapshots in time (Coleman 1979; Ridding et al. 2015). But there are few studies which have assessed change in all habitats across large regional landscapes at multiple time points. An exception to this is the Countryside Survey which has assessed the extent and condition of broad habitats in the UK using $1 \mathrm{~km}$ survey squares at discrete intervals since 1978 (Barr et al. 1993; Carey et al. 2008).

In the UK, as elsewhere in western Europe, the decline in semi-natural habitats in recent decades has been attributed to three major types of land use change; agricultural intensification, urban development and afforestation (Watson and Albon 2011). These three major land use changes increased rapidly after the Second World War, at the start of the period known as the "Great Acceleration", when the impact of human activity on the state and functioning of the Earth System increased significantly (Steffen et al. 2007, 2015). Agricultural intensification accelerated in the 1940s due to the Agriculture Act of 1947 (Best and Coppock 1962). This continued following the UK's accession to the European Union (EU) in 1973, causing semi-natural grasslands and heathlands to be converted to arable or fertilised for grass production. Over the same period, semi-natural habitats were also being lost to conifer plantations, due to the importance 
of economic forestry resulting from a Treasury policy review in 1957 (Aldhous 1997). This continued until the 1980s, when policy changes promoted planting of deciduous trees (Nail 2008). Urbanisation has also increased over the last 60 years. In the UK urban growth during the 1950s was greatest in the most urbanised regions (Parry et al. 1992). However in the latter half of the twentieth century urban sprawl increased as richer people moved away from urban centres, which led to a greater loss of countryside (Zhang 2016). Although the three major land use changes which have led to the loss of semi-natural habitats in the UK are known, few have examined the trends over time using long-term land cover data.

As elsewhere in the world, a number of policies and laws have been developed in the UK in an attempt to reduce further losses of semi-natural habitats. These range from European-wide legislations to local planning policies which aim to prevent damaging activities. European protected sites include Special Protection Areas for birds and Special Areas of Conservation. Sites that are nationally important in the UK for their flora, fauna, or geological or physiographical features are protected by law as Sites of Special Scientific Interest (SSSIs, or Areas of Special Scientific Interest, ASSIs, in Northern Ireland) (JNCC 2015). All sites protected by European and national legislation must be considered in the UK planning process. The National Planning Policy Framework sets out government's planning policies for England which requires that local authorities must ensure that any developments have minimal impact on biodiversity. Although the importance of protected areas for biological conservation is acknowledged, there is little empirical evidence of their effectiveness (Gaston et al. 2008; Greve et al. 2011). Given the importance placed on protected areas, it is important to understand if they are effective in preventing or slowing habitat loss.

Dorset is a pre-dominantly rural county in southern England (Fig. 1), which like many other regions across Europe experienced dramatic intensification of land use during the last century. In addition, a large survey of habitats was carried out during the 1930s, which presents a unique historical baseline. This makes Dorset an ideal case study to examine habitat change over time, with findings being representative of many western European lowland landscapes (Hooftman et al. 2016). In this paper we quantify changes in semi-natural habitats across the Dorset landscape at five time points between 1930 and 2015, using survey data and contemporary spatial datasets in GIS. Based on the evidence reviewed above we aim to address the following questions;

(i) Has the loss of semi-natural habitats been linear over time?

(ii) What are the main drivers of loss for each semi-natural habitat, and do these change over time?

(iii) Do protected sites have lower rates of change than other areas of semi-natural habitat?

\section{Method}

To quantify changes in semi-natural habitats across Dorset over time, we generated a time series of habitat/land cover for 1930, 1950, 1980, 1990 and 2015 (Fig. 2). The starting point for the time series used Ronald Good's vegetation survey undertaken between 1931 and 1936. Good undertook a systematic survey of vascular plant species using the 'stand' method (see Good 1937) at 7575 sites across Dorset (referred to subsequently as "Good sites") with the aim of producing distribution maps for single species. Stands were '....reasonably distinct topographical and ecological entit[ies]...' and were required to be '.... as evenly scattered as possible' across Dorset with an average of 5-6 stands per square mile (Good 1937, p. 115). The "Good sites" were recorded on a series of six-inch to the mile $(1: 10,560)$ Ordnance Survey (OS) maps which were later digitized by the Dorset Environmental Records Centre (DERC), along with site and species information, which included a species list of all vascular plants encountered whilst Good traversed each site. Sites varied in size, ranging from ca. 0.5 to 70 ha. In the 1980 s, 6880 of these sites were revisited by Anne Horsfall, who simply determined whether the original habitat remained or not. These 6880 Good sites where the habitat type was known for the two time points were used alongside historical OS maps and contemporary land cover spatial layers to construct a habitat time series (Fig. 2). 


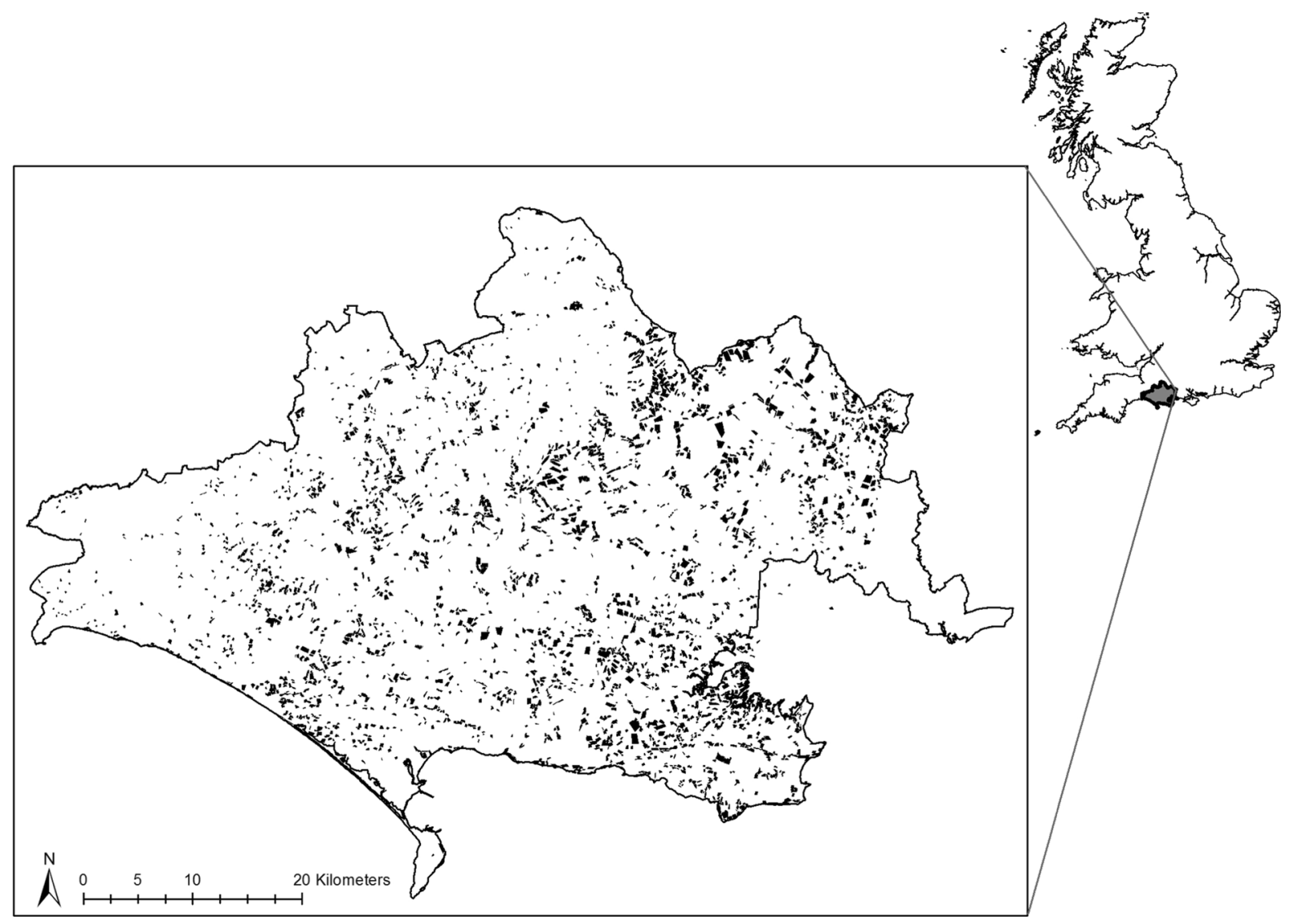

Fig. 1 Location of sites within Dorset, south England. County boundary excludes the boroughs of Poole and Bournemouth, which were not part of Dorset in the 1930 s

Habitat extent in the 1930s

DERC allocated a broad habitat type to each site based on the descriptions provided in Good's diaries (Good 1937), which are closely aligned to those defined by Jackson (2000) for UK habitat types in general (Table 1, first column). We used two other datasets to validate the assigned broad habitat type for the 1930s. Firstly, we intersected the sites with the adapted Dudley Stamp Map created by Hooftman and Bullock (2012) in ArcGIS v10.4 (C) ESRI, Redlands, CA). The Dudley Stamp Map was created from the 1930s Land Utilisation Survey of Britain, where volunteers mapped land-use on OS maps (Stamp 1931). Secondly, we ran Good's plant species records for each site through Tablefit (Hill 1996), to determine the National Vegetation Classification (NVC) community. The NVC classifies the plant communities of Britain (Rodwell 1992). Using the classification table in Ridding et al. (2015), we assigned the NVC community for each site to one of the broad habitats detailed in Table 1 . Over $75 \%$ of sites were assigned a broad habitat which was consistent across two or three of the datasets (Good description, Dudley Stamp Map, NVC community). For the remaining sites whose habitat classification differed across the three datasets, we used the Good description to designate the habitat type, since these direct survey data are likely to be more reliable than the other two datasets. We removed all sites which were designated as "hedgerows" in the 1930s, since these sites were too small to assess accurately in the later time periods $(\mathrm{n}=2042)$ as the Land Cover Maps (see below) do not map linear or boundary features (Fig. 2). 


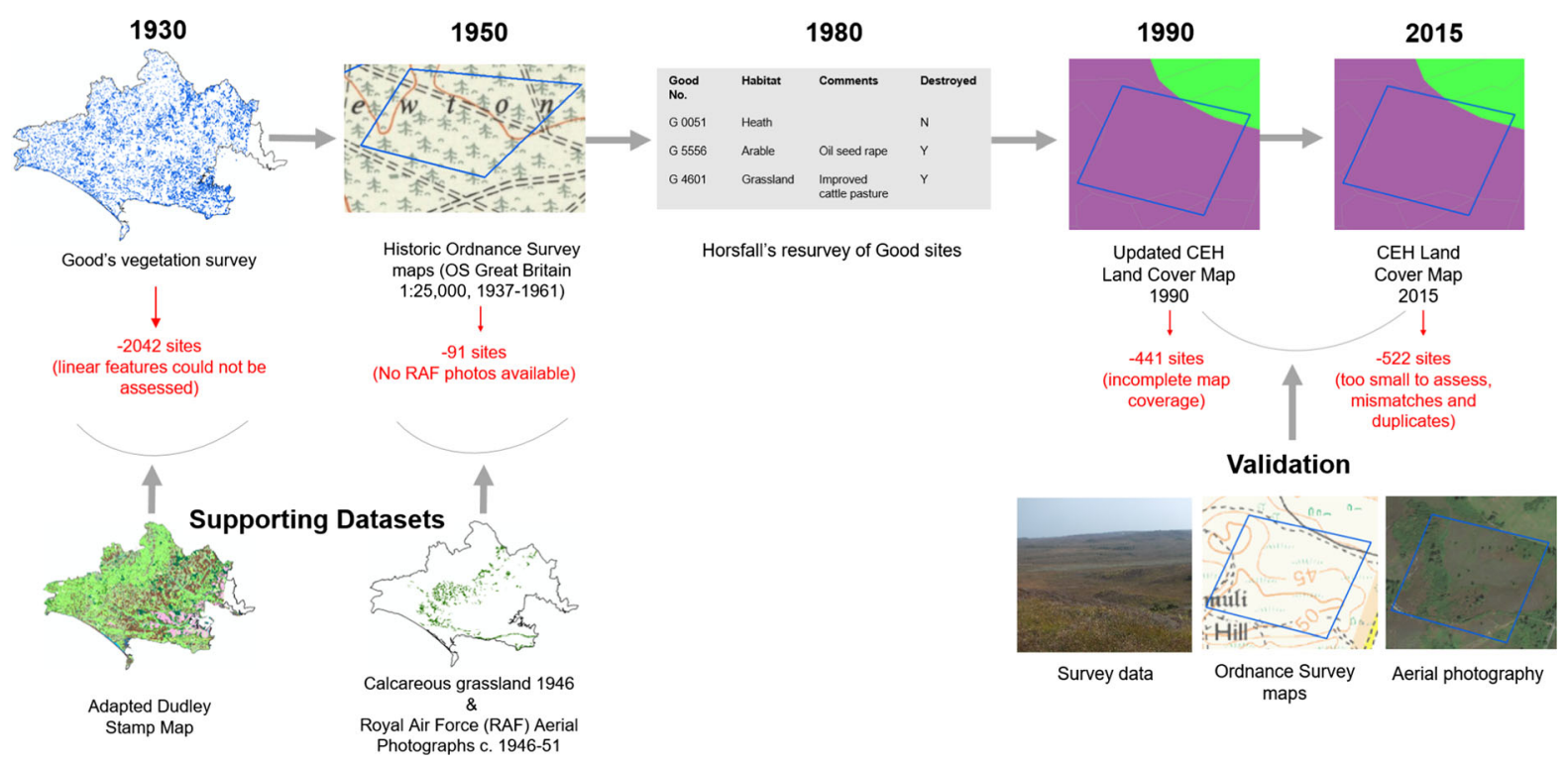

Fig. 2 The methodology used to determine habitat cover within each Good site for 1930 (Good 1937), 1950 (Ordnance Survey 1961), 1980 (Horsfall 1981), 1990 (Rowland et al. 2017b) and 2015 (Rowland et al. 2017a), with the validation datasets (Ordnance Survey (2017), (C ESRI World Imagery), supporting

Habitat extent in the 1950s

For sites which had remained the same habitat in 1980 (determined by Horsfall) as in the 1930s, we assumed the same habitat in the 1950s (3892 sites). For the remainder, we utilised the OS Great Britain 1:25,000, 1937-1961 (Ordnance Survey 1961) map series to determine the habitat cover during the 1950s. This OS series comprised 10 kilometre squares across Great Britain, and most of the individual 10 kilometre square maps including Dorset were completed around the 1950s. Since the OS maps displayed particular symbols for certain habitats (see Fig. 2) we could distinguish the main habitat for most sites (coniferous and broadleaved woodland, water, urban, heath, marsh and grassland), which we classified according to the broad habitat types (Table 1). For some sites that were seminatural grassland in the 1930s, no markings were present on the 1950s OS map to indicate the habitat type. We used a GIS layer of calcareous grassland habitat in 1946 created by DERC using a variety of sources including Royal Air Force (RAF) Aerial Photographs c. 1946-51, OS maps and The Conservation of Chalk Downland in Dorset, 1973 (see Edwards, 2006), to indicate which sites were still datasets (adapted Dudley Stamp Map re-created from Hooftman and Bullock (2012), calcareous grassland map re-created from DERC data) and the number of sites removed from each stage in the analysis

calcareous grassland. The remaining unclassified sites which were semi-natural grassland in $1930(\mathrm{n}=550)$, were thus likely to be either arable, improved grassland or another type of semi-natural grassland. To distinguish these, we utilised RAF Aerial Photographs c. 1946-51 (Dorset County Council 2018). Arable fields were open with furrows, interpreted as a sign of ploughing, whilst pastures were open without furrows, often with grazing animals present. Darker colours and "rough patches" were used to distinguish between unimproved and improved grassland. This technique was very time-consuming, so was only employed where other methods failed to identify the habitat. Aerial photographs were unavailable for 91 sites, and so these were removed from further analysis. Where the 1930s habitat had clearly been lost, but the OS map did not give any indications as to the current habitat, we assigned the habitat present in the 1980s.

Habitat extent in the 1980s

Sites were revisited by Anne Horsfall in the 1980s (see Horsfall, 1981). Using Good's plant list for each site, Horsfall determined whether the habitat reported in the 1930s remained or had changed. She recorded the 
Table 1 Broad habitat classifications for 1930, 1950 and 1980, matched with categories from the Land Cover Map 2015, alongside the final combined habitat classification for the whole time series

\begin{tabular}{|c|c|c|}
\hline Broad habitat $(1930,1950,1980)$ & Land cover map habitat $(1990,2015)$ & Combined time-series habitat classification \\
\hline Rivers and streams & Freshwater & Water \\
\hline \multicolumn{3}{|l|}{ Standing open water and canals } \\
\hline Bracken (excluding 1950) & N/A & Mosaic \\
\hline Arable and horticulture & Arable and horticulture & Arable and horticulture \\
\hline Bog & Bog & N/A (not found in Dorset) \\
\hline Fen, marsh and swamp & Fen, marsh and swamp & Fen, marsh and swamp \\
\hline Acid grassland & Acid grassland & Acid grassland \\
\hline Calcareous grassland & Calcareous grassland & Calcareous grassland \\
\hline Neutral grassland & Neutral grassland & Neutral grassland \\
\hline Improved grassland & Improved grassland & Improved grassland \\
\hline Heathland & Dwarf Shrub Heath & Heathland \\
\hline Boundary and linear feature & N/A & N/A (removed these sites) \\
\hline Inland rock & Inland rock & Inland rock \\
\hline N/A & Saltwater & Coastal \\
\hline Littoral rock & Littoral rock & \\
\hline Littoral sediment & Littoral sediment & \\
\hline Supra-littoral rock & Supra-littoral rock & \\
\hline Supra-littoral sediment & Supra-littoral sediment & \\
\hline \multirow[t]{2}{*}{ Built-up areas and gardens } & Urban & Urban \\
\hline & Suburban & \\
\hline Broadleaved woodland & Broadleaved, mixed and yew woodland & Broadleaved, mixed and yew woodland \\
\hline Coniferous woodland & Coniferous woodland & Coniferous woodland \\
\hline
\end{tabular}

Bracken is not mapped in the LCMs, as the consistency cannot be guaranteed across the country (Rowland et al. 2017a); therefore it is often associated with the other broad habitat types. It was also impossible to detect sites which were solely bracken in the 1950s using the OS maps, so these sites were grouped under a "Mosaic" category. We grouped "Littoral Sediment", "Littoral Rock", "Supralittoral Sediment", "Supra-littoral Rock" categories used in the LCMs into a "Coastal" category, because for some sites the habitat switched between two of these coastal types in the two LCMs, which likely reflects classification issues rather than habitat change

general habitat alongside additional notes, which we used to classify each site into a broad habitat type (Table 1). We made some assumptions during the classification process in order to assign woodland sites to coniferous or broadleaved woodland. For most sites where plantations were present in the 1980s, Horsfall had made additional notes allowing us to determine whether the plantation was broadleaved, coniferous or mixed. For a small number of sites $(<10)$ Horsfall provided no information, and we assumed a coniferous plantation since the majority of British tree planting in the mid twentieth century was coniferous (Mason 2007). We also assigned improved grassland for all of the sites which Horsfall described as pastures. For the majority of sites, this was confirmed by notes provided by Horsfall (Fig. 2).
Habitat extent in 1990 and 2015

To determine the habitat at each site in 1990, we used an updated dataset of the UK Land Cover Map 1990 (LCM1990) (Rowland et al. 2017b). The original LCM1990 (Fuller et al. 1993), is not directly comparable with Land Cover Map 2015 (LCM2015) (Rowland et al. 2017a) because it uses different land cover classes and has a different spatial structure. To make it comparable with LCM2015, our updated 1990 Land Cover dataset (Rowland et al. 2017b), was created using the same methodology as that used to create the LCM2015. Using ArcGIS on the revised LCM1990, we assigned the habitat for each site as that with the largest percentage cover in the site. Since the updated LCM1990 does not yet have full coverage across 
Dorset, 441 sites could not be assessed and were removed from the study (Fig. 2). We used the same methodology with LCM2015 to identify the main habitat type for each site in 2015.

\section{Combining habitat time series data}

Habitat data for the 1930s, 1950s, 1980s, 1990 and 2015 were standardised using Table 1 . The habitat classifications from the 1930s, 1950s, 1980s and the LCMs were largely similar, as they were all based on Jackson (2000) broad habitat categories. We generated transition matrices between each time period, with partially converted sites being classified as lost. This highlighted any apparent habitat changes that were unlikely to occur in reality, for example acid grassland converting to calcareous grassland. Where unlikely conversions were identified in 1990 (where both 1980 and 2015 remained consistent), we checked aerial photography for the closest time period available, 2002 (Dorset County Council 2018). This resolved issues for a number of urban sites, which were identified as improved grassland in the LCMs due to large gardens with extensive lawns. This left a total of 3784 sites for analysis, where the broad habitat was known in each time period. Since the methodology we used for classifying habitats in the latter periods (1990 and 2015 used the Land Cover Maps), was quite different from the previous time points, we performed validation using additional datasets to assess the accuracy and consistency of the time series across all periods, which we describe in Appendix 1. This provided us with a high level of confidence in our classifications.

\section{Statistical analysis}

To examine whether the losses of semi-natural habitats (acid grassland, broadleaved woodland, calcareous grassland, fen, marsh and swamp, heathland and neutral grassland) were linear over time, we constructed general linear models (GLMs) and generalized additive models (GAMs), with year as the dependent variable. GAMs are often used to detect non-linearity in time series data (Granadeiro et al. 2004; Watson et al. 2018). Where the AIC difference between the GLM and GAM was less than 2, we took this as providing evidence for little difference between the models (Burnham and Anderson 2002), and so the
GAM model was rejected and we concluded the pattern was linear. Where this was not the case, we included year as a smoother term in the GAM model using the "mgcv" package (Wood 2017) in R v3.0.2 (R Core Team 2017).

For each time period, we identified those sites in which the habitat type changed and used Chi squared tests to examine whether new habitat types fitted a null hypothesis of a random distribution of different types. Separate Chi squared tests were performed according to the original habitat type; neutral grassland, calcareous grassland, fen, marsh and swamp, heathland and acid grassland. When assessing what habitats changed into, those with a low coverage were combined into an "other" category (coastal, water, fen, marsh, swamp, acid grassland, calcareous grassland, heathland, mosaic and inland rock) for this analysis. Where the assumptions required for a Chi squared test were not met, we used Fisher's exact test for small sample sizes.

Protected sites were determined using the digital boundary data for SSSIs in ArcGIS (Natural England 2014). SSSIs were first established in the 1950s, but were later re-notified under the Wildlife and Countryside Act 1981, with sites still being added until present, but to a much lesser extent (see Ridding et al., 2015). SSSIs were chosen to represent protected areas in the UK since this system provides the underpinning statutory protection for all sites, including those which are of European importance. Sites were classified as protected if at least $90 \%$ of their area fell within the SSSI boundary, which accounted for small differences in the borders of both datasets. We then calculated the turnover at each site, with turnover defined as the number of time periods in which the habitat changed (Swetnam 2007). To examine whether protected sites were more likely to have no turnover, we used a Chi squared test to determine if the number of sites with no habitat turnover fitted a null hypothesis of equal distribution between protected and unprotected sites. Individual tests were performed according to the original 1930s habitat of the site: acid grassland, calcareous grassland, fen, marsh and swamp, heathland and neutral grassland. 


\section{Results}

Trends in semi-natural habitats

There were considerable losses across the majority of semi-natural habitat sites examined -including acid grassland, calcareous grassland, fen, marsh and swamp, heathland and neutral grassland -in Dorset between 1930 and 2015 (Fig. 3). Of the 3146 seminatural habitat sites assessed, $62 \%$ of sites remained as their original habitat in 2015. The greatest losses were found for neutral grassland, with $97 \%$ of sites lost between across the Dorset landscape between 1930 and 2015 , followed by a loss of $70 \%$ for calcareous grassland. Broadleaved woodland remained fairly consistent with a slight linear increase overall (3\%), though it did experience declines between 1930 and 1980. The majority of the declining semi-natural habitats, including acid grassland, calcareous grassland, heathland and neutral grassland, decreased nonlinearly over time (Table 2). The greatest declines occurred between 1930 and 1980, with the highest losses occurring between 1950 and 1980, after which the loss of sites appeared to level-off for some habitats. Fen, marsh and swamp habitats were the only seminatural habitat type to decline linearly between 1930 and 2015 (Table 2).

\section{Timing of habitat conversion}

Intensive land cover types within the landscape including coniferous woodland, improved grassland, arable and urban areas increased rapidly, at the expense of semi-natural habitat sites, largely between 1930 and 1980 (Fig. 3). The greatest increase in the number of improved grassland and arable sites occurred between 1950 and 1980, which corresponds to the period with the highest percentage loss of seminatural habitat sites $(-20 \%)$. For urban and coniferous woodland, the greatest gains were between 1930 and 1950. After 1980 the number of sites converted to the intensive land covers decreased (Fig. 3). This was particularly clear for arable, coniferous woodland and urban, which showed non-linear trends (Table 2) and evidence of levelling off in the later time period, with some arable sites even being lost between 1990 and 2015. Improved grassland, on the other hand, increased linearly throughout the survey period.
Drivers of change for semi-natural habitats

The types of land cover to which semi-natural sites were converted to differed significantly across the landscape among neutral grassland, calcareous grassland, fen, marsh and swamp, heathland and acid grassland sites in 1950, 1980, 1990 and 2015 (Table 3). Considerable proportions of semi-natural habitat were lost to arable before 1980 (Fig. 4), particularly calcareous and neutral grassland, with only small proportions from acid grassland, fen, marsh and swamp, and heathland. Large percentages of seminatural habitat were also converted to improved grassland, where in 1980 at least $45 \%$ of each of the semi-natural habitats had been lost to improved grassland. The proportions increased further in 1990 and 2015 for neutral, acid and calcareous grassland, where in 1990 and 2015 conversion to improved grassland accounted fully for the loss of acid grassland and neutral grassland. A number of fen, marsh and swamp, and heathland habitats were converted to broadleaved woodland, possibly due to scrub encroachment. Coniferous woodland was responsible for the majority of heathland loss in 1950, 1990 and 2015, with some conversion of heathland to improved grassland and smaller proportions being lost to broadleaved woodland and urban areas (Fig. 4).

Land cover change in protected sites

The majority of sites which were protected via designation as a SSSI had 0 turnover (75\%), meaning the semi-natural habitat classified for 1930 remained between 1950 (post designation) and 2015 (Fig. 5). Turnover was greater in the non-protected sites (only $31 \%$ had 0 turnover), with the majority of sites having at least one habitat change. This was the case for calcareous grassland $\left(X^{2}=9.93, d f=1, p=0.002\right)$, acid grassland $\left(X^{2}=24.06, d f=1, p<0.001\right)$, heathland $\left(X^{2}=5.74, d f=1, p=0.017\right)$ and fen, marsh and swamp $\left(X^{2}=4.70, d f=1, p=0.030\right)$, though protection did not affect the retention of neutral grassland between 1950 and $2015\left(X^{2}=1.03, \quad d f=1\right.$, $p=0.310)$. 
Fig. 3 The number of sites for each semi-natural habitat (acid grassland, broadleaved woodland, calcareous grassland, fen, marsh and swamp, heathland, neutral grassland) and intensive land use type (arable, coniferous woodland, improved grassland, urban) across Dorset in 1930, 1950, 1980, 1990 and 2015. Trend lines with $95 \%$ confidence intervals indicated in grey, represent the fitted general linear models for improved grassland, broadleaved woodland and fen, marsh and swamp, and the generalized additive models for acid grassland, calcareous grassland, heathland, neutral grassland, arable, coniferous woodland and urban
Acid grassland

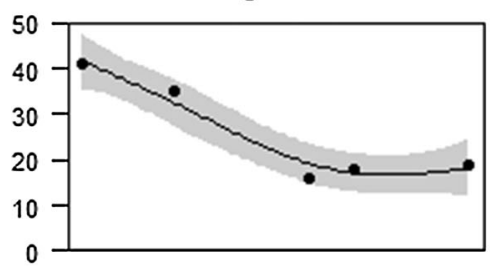

Calcareous grassland

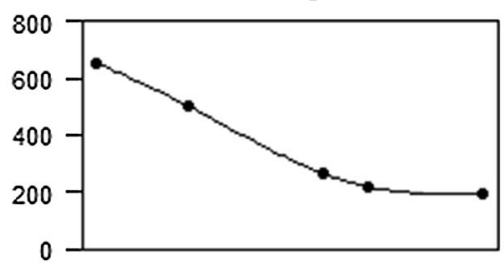

Heathland

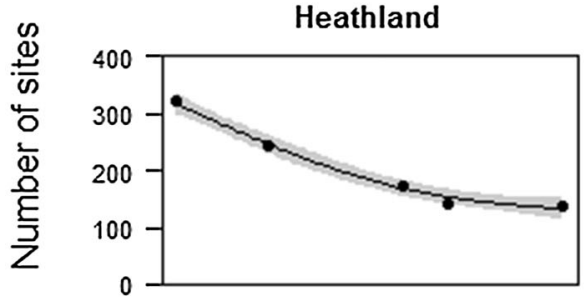

Arable

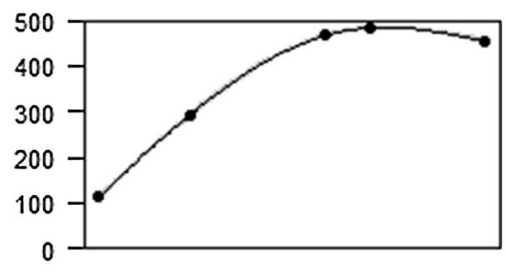

Improved Grassland

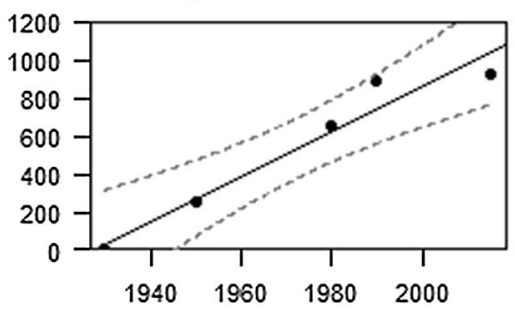

Broadleaved woodland

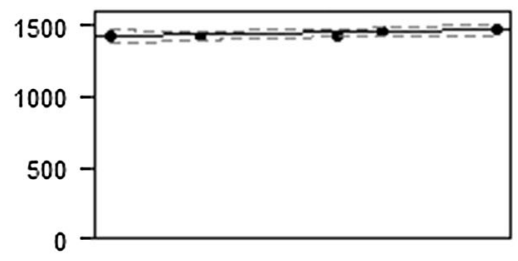

Fen, marsh, swamp

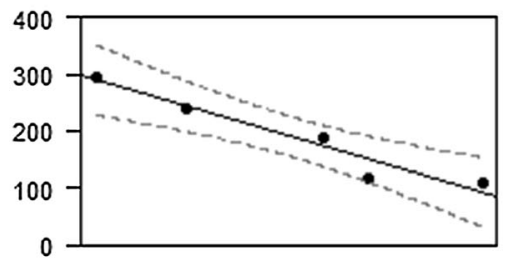

Neutral grassland

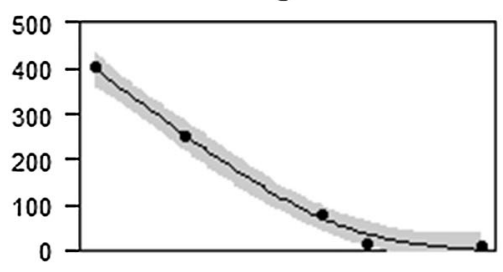

Coniferous Woodland

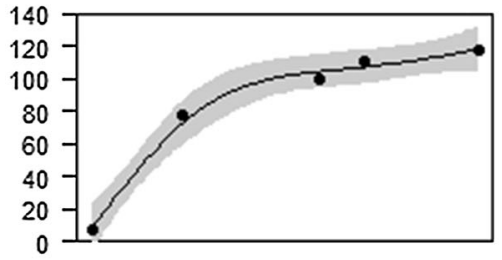

Urban

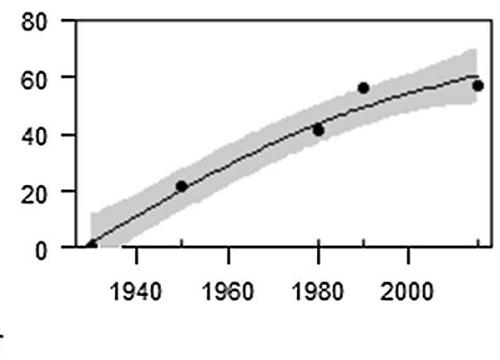

\section{Discussion}

We have identified changes in habitat types by assessing more than 3700 sites in the Dorset landscape between 1930 and 2015 over five consecutive time intervals. The creation of this novel dataset for
Dorset's semi-natural habitats has provided a rare opportunity to examine the loss of habitats, the patterns of change and the fate of sites across multiple time periods in a region which is broadly representative of many lowland landscapes in western Europe that have a predominantly agricultural land use. 
Table 2 GLM and GAM results including AIC, $\mathrm{R}^{2}$ and smoother term values (edf $=$ estimated degrees of freedom) (for latter only) used to examine whether trends in semi-natural habitat (acid grassland, broadleaved woodland, calcareous grassland, fen, marsh and swamp, heathland, neutral grassland) and land cover (arable, coniferous woodland, improved grassland, urban) were non-linear between 1930 and 2015 in Dorset

\begin{tabular}{|c|c|c|c|c|c|c|c|}
\hline \multirow[t]{2}{*}{ Habitat/land cover } & \multicolumn{5}{|l|}{ GAM } & \multicolumn{2}{|l|}{ GLM } \\
\hline & AIC & $\mathrm{R}^{2}$ & $p$ & $\mathrm{~F}$ & edf & AIC & $\mathrm{R}^{2}$ \\
\hline Acid grassland & 29.16 & 0.92 & 0.079 & 17.61 & 2.32 & 35.68 & 0.72 \\
\hline Broadleaved woodland & 45.06 & 0.60 & 0.196 & 3.01 & 1.59 & 46.79 & 0.42 \\
\hline Calcareous grassland & 23.25 & 1 & 0.002 & 13,169 & 3.00 & 59.44 & 0.90 \\
\hline Fen, marsh, swamp & 49.70 & 0.91 & 0.007 & 39.12 & 1 & 49.70 & 0.91 \\
\hline Heathland & 41.13 & 0.98 & 0.018 & 80.12 & 2.24 & 50.57 & 0.88 \\
\hline Neutral grassland & 47.73 & 0.99 & 0.020 & 96.59 & 2.37 & 58.36 & 0.88 \\
\hline Arable & 34.40 & 0.99 & $<0.001$ & 1770 & 1.99 & 61.88 & 0.73 \\
\hline Coniferous woodland & 36.66 & 0.97 & 0.075 & 47.53 & 2.81 & 48.51 & 0.76 \\
\hline Improved grassland & 62.34 & 0.95 & 0.018 & 38.87 & 1.81 & 64.83 & 0.92 \\
\hline Urban & 34.93 & 0.95 & 0.020 & 33.72 & 1.76 & 37.88 & 0.93 \\
\hline
\end{tabular}

Table 3 Chi squared test results for examining whether current land cover across lost habitat sites were randomly distributed for acid grassland, calcareous grassland, fen, marsh and swamp, heathland and neutral grassland across the four time periods; 1950, 1980, 1990 and 2015 in Dorset

\begin{tabular}{|c|c|c|c|c|c|c|c|c|c|c|c|c|}
\hline & \multicolumn{3}{|l|}{1950} & \multicolumn{3}{|l|}{1980} & \multicolumn{3}{|l|}{1990} & \multicolumn{3}{|l|}{2015} \\
\hline & $X^{2}$ & $d f$ & $p$ & $X^{2}$ & $d f$ & $p$ & $X^{2}$ & $d f$ & $p$ & $X^{2}$ & $d f$ & $p$ \\
\hline Acid & - & - & $<0.001$ & 68.24 & 5 & $<0.001$ & - & - & $<0.001$ & - & - & $<0.001$ \\
\hline Calcareous & 63.78 & 5 & $<0.001$ & 77.68 & 5 & $<0.001$ & 73.48 & 5 & $<0.001$ & 68.10 & 5 & $<0.001$ \\
\hline Fen, marsh, swamp & 24.90 & 5 & $<0.001$ & 48.58 & 5 & $<0.001$ & 57.21 & 5 & $<0.001$ & 43.85 & 5 & $<0.001$ \\
\hline Heathland & 52.09 & 5 & $<0.001$ & 21.36 & 5 & $<0.001$ & 14.78 & 5 & 0.010 & 64.29 & 5 & $<0.001$ \\
\hline Neutral & 74.41 & 5 & $<0.001$ & 89.85 & 5 & $<0.001$ & 72.40 & 5 & $<0.001$ & - & - & $<0.001$ \\
\hline
\end{tabular}

Where assumptions required for a Chi squared test were not met $\left(X^{2}=-\right)$, Fisher's exact results are presented

Trends in semi-natural habitats

We found considerable losses over 85 years for the majority of semi-natural habitats across the Dorset landscape, including neutral grassland, calcareous grassland, fen, marsh and swamp, acid grassland and heathland. This is consistent with other studies in Dorset (Rose et al. 2000; Hooftman and Bullock 2012), the UK (Fuller 1987; Ridding et al. 2015) and across Europe (van Dijk 1991; Piessens and Hermy 2006). The NCC (1984) revealed a loss of $70 \%$ of chalk grassland in Dorset between 1934 and 1972, which is the same as the loss we report between 1930 and 2015. For the majority of habitats in Dorset, the decline was non-linear between 1930 and 2015. The greatest losses occurred during 1950 and 1980, after which the decline in semi-natural habitats decreased. While this might be seen as a positive for conservation, it is mostly due to the fact that there was very little habitat left in this landscape by this period. For instance, only 12 of the original 401 neutral grassland sites remained in 2015. However, other factors including the timing of drivers (discussed below) and the designation of SSSIs and other similar protection schemes, will have increasingly prevented damaging activities on many semi-natural habitats (JNCC 2015).

The non-linear trend of habitat loss revealed in this study has important implications for the reporting of biodiversity change over time, since many long-term 
Fig. 4 The percentage of acid grassland, calcareous grassland, fen, marsh and swamp (FMS), heathland and neutral grassland sites which converted to a more intensive land cover (arable, coniferous woodland, improved grassland, urban), broadleaved woodland and other in Dorset in 1950, 1980, 1990 and 2015

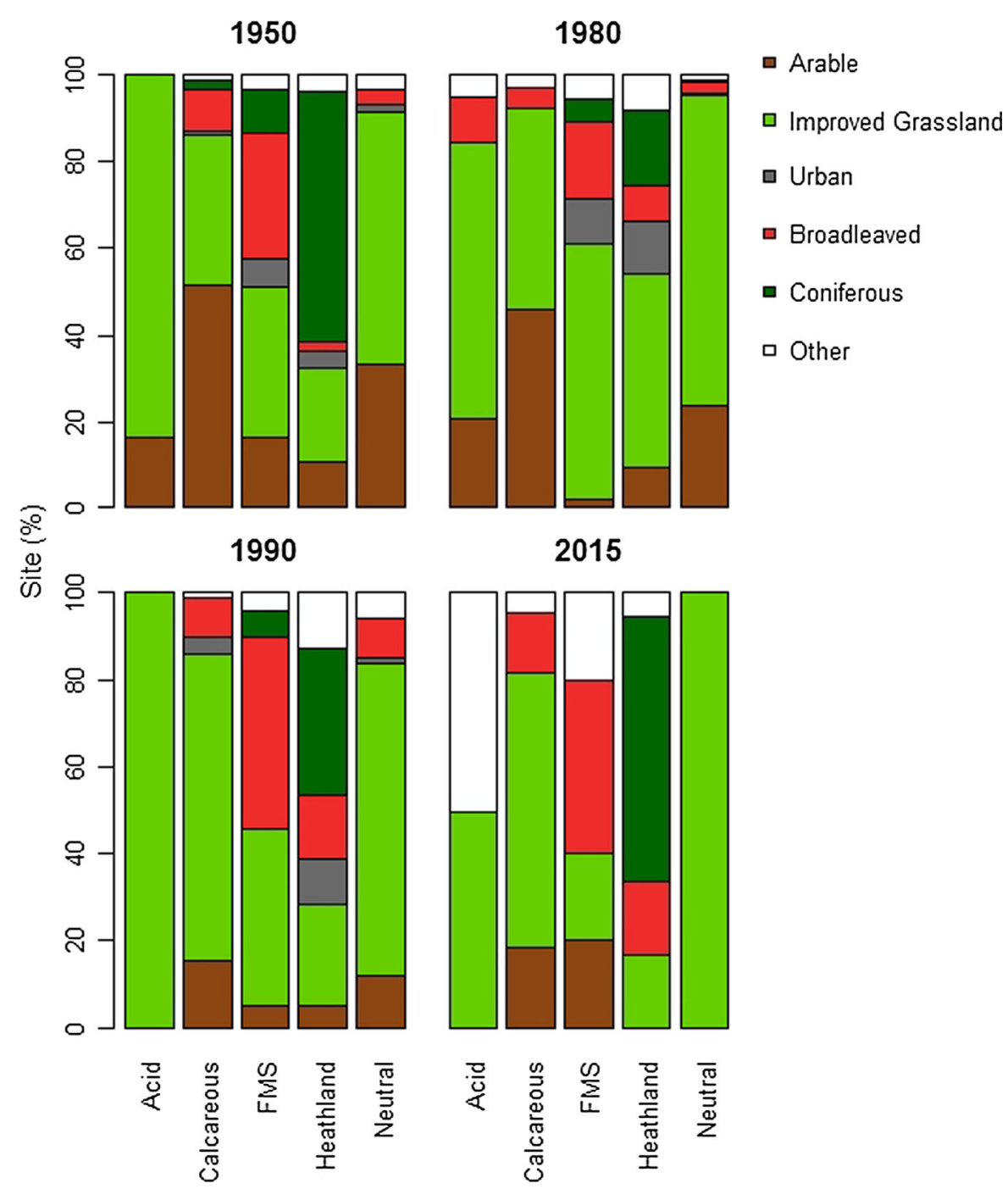

studies often focus on the last forty years at best. For instance, Hallmann et al. (2017) reported a 76\% decline in flying insect biomass German protected areas between 1989 and 2016, whilst Powney et al. (2019) showed that one-third of insect pollinator species experienced declines between 1980 and 2013 in Great Britain. Both studies evaluated species' trends after 1980, by which time the majority of semi-natural habitats were already lost in our study. Indeed, data on biodiversity loss to inform reporting to the Convention on Biological Diversity goes back to the 1970s at most in the UK (DEFRA 2018), a country with one of the longest histories of monitoring in the World (Pocock et al. 2015). There are few exceptions to this, for example Hambler et al. (2011) examined extinction debts in Britain going back to the 19th century. This still raises the question as to what species loss occurred during the earlier period of massive habitat loss before such recording started. Indeed, the "shifting baseline syndrome" addresses the problem that a lack of understanding of historic losses may cause an acceptance of the current low biodiversity state as being normal (Soga and Gaston 2018). Furthermore, ongoing species' declines may be a delayed response to this past habitat loss, i.e. the paying of extinction debts (Sang et al. 2010). Hooftman et al. (2016) found that plant extinctions in intact habitat in Dorset were driven by declining connectivity as a result of landscapescale habitat loss. This also suggests that even if 


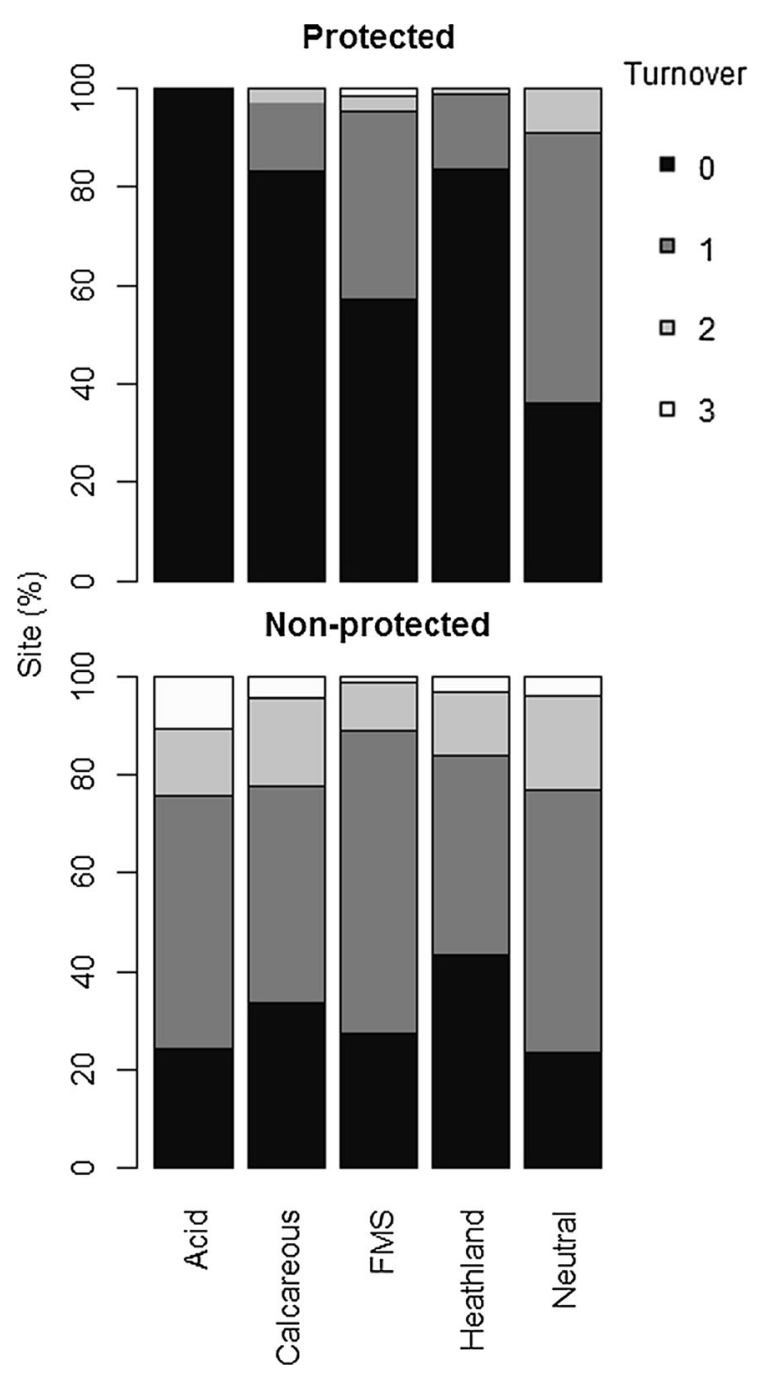

Fig. 5 The turnover of protected and non-protected sites across Dorset between 1950 (post protection designations) and 2015 for sites which were acid grassland, calcareous grassland, fen, marsh, swamp (FMS), heathland and neutral grassland in 1930, where a turnover of 0 indicates the habitat has not changed

habitat loss completed ceased, which is not yet evident in Dorset, losses in biodiversity may continue.

Timing of habitat conversion

Between 1930 and 2015 a number of land cover types, representing intensive land uses, increased considerably across the Dorset landscape, including arable, improved grassland, coniferous woodland and urban areas. Arable and improved grassland increased the greatest from 1950 to 1980 , which suggests that habitat conversion to these land covers did not necessarily occur immediately after the Second World War and continued after the UK's accession to the EU in 1973 (Fuller 1987). The number of sites converted to arable fell after the 1980s, around the time where crop yields tripled in the UK (Pretty et al. 2000), through mechanisation and chemical application, meaning less area was required to maintain yields. Agri-environment schemes were also introduced, while a number of economic and political factors led to a reduction in the number of farms, including falls in prices for agricultural products and farm income, as well as diseases affecting cattle such as Mad Cow Disease (BSE) and Foot and Mouth (Zayed 2016).

In the period 1990-2015 the number of arable sites decreased for the first time during the study period. The European Environment Agency (EEA) found that urbanisation was predominantly occurring on arable land between 1990-2000 (European Environment Agency 2010) and 2006-2012 (European Environment Agency 2017), but in Dorset we found no evidence of this. Instead the main change to arable sites 1990-2015 was conversion to improved grassland. This most likely reflects the agricultural system in the UK, whereby grass and clover leys are often added to arable rotations, to manage weed problems such as black grass or to increase soil fertility (AHDB 2018).

The majority of urbanisation in Dorset occurred during 1930-1950 in our study, which includes the period immediately after the Second World War. During this time no planning permission was required for land development, until the Town and Country Planning Act was established in 1947. Following this period there was a reduction in the number of sites converted to urban, despite the fact that this land cover is predicted to increase across Europe in the future (European Environment Agency 2017). This may be because Dorset is a predominantly rural county (Hooftman and Bullock 2012), where urban pressures are largely confined to the main towns of Bournemouth and Poole (Webb and Haskins 1980). None of our sites occurred in these areas, since they were not examined in the original Good survey (Good 1937).

The biggest increase in coniferous woodland in Dorset was also in the period 1930-1950. For coniferous woodland this was largely driven by the formation of the Forestry Commission in 1919 and the objective of having a strategic supply of timber which led to extensive planting until 1980 when the 
emphasis shifted towards sustainable forestry (Mason 2007). This mirrors the findings in this study in which a non-linear trend in afforestation is evident, with a slowing in the later periods. Afforestation was also found to be one of the most important processes for landscape change across Europe (Bürgi et al. 2017).

Although the loss of semi-natural habitats to agricultural intensification, urban development and afforestation was highest following the Second World War until the 1980s, there were considerable losses in the landscape after this period. This suggests that the three drivers of change are still a threat to biodiversity in the present day. This has important implications for conservation and landscape management in the future. Indeed, the pattern of urbanisation is currently changing in Dorset and elsewhere in England as house building is expanding into more rural areas (Campaign to Protect Rural England 2018). Agriculture could continue its gradual expansion under policies aimed at increasing food production (Reif and Vermouzek 2019) or under new post-Brexit agricultural policies. Conversely policies for a more sustainable future might facilitate expansion and restoration of seminatural habitats, as promised under the UK Government's 25 Year Environment Plan (Isaac et al. 2018) and more widely for the UN's Sustainable Development Goals.

Differences among semi-natural habitats in drivers of change

There were significant differences in the drivers of loss among the different semi-natural habitats during different time periods. More calcareous grassland sites were lost to arable land after the 1940s compared with neutral grassland, acid grassland and fen, marsh and swamp. Ridding et al. (2015) found that although greater numbers of mesotrophic sites were lost throughout England between 1960 and 2013 compared with calcareous grassland, the proportion of sites which were converted to arable was greater for calcareous grassland compared with mesotrophic grassland, wet grassland and lowland heath and dry acid grassland, which is consistent with our study. Considerably fewer acid grassland and fen, marsh and swamp habitats were converted to arable compared with calcareous and neutral grassland, which is most likely due to; a) more constrained soils that are less fertile for arable agriculture; and b) the lack of advances in drainage technology until the 1980s (Green 1990).

Conversion to improved grassland was a key driver of change for most semi-natural habitats throughout the study period, particularly for acid, calcareous and neutral grassland after 1950. Some of these changes may have been due to fertiliser application or reseeding, however some changes may be attributable to more subtle processes such as nitrogen deposition or grazing management, rather than land-use change per se (Maskell et al. 2010; Diekmann et al. 2014). A resurvey of Good's calcareous grassland sites in 2009 revealed a shift from species typical of species-rich calcareous grasslands towards those more typical of mesotrophic grassland, with eutrophication and management changes suggested as potential causes (Newton et al. 2012).

During all time points, excluding 1950-1980, afforestation was the greatest driver of heathland loss. The large conversion to coniferous woodland in the 1950s corresponds to the period where conifer planting was promoted, as previously mentioned. Heathland losses to coniferous woodland in 1990 and 2015 were likely to be a result of inappropriate management. Diaz et al. (2013) conducted a re-survey of the original Good heathland sites in 2010 and also found that vegetation shifted towards a woodland community, whilst Rose et al. (2000) reported increases in scrub and woodland on heathland in between 1987 and 1996. This supports the findings of heathland also being lost to broadleaved woodland in this study, which is largely attributed to the reduction in rough grazing and controlled burning (Moore 1962). Urbanisation was also a driver of heathland loss in Dorset, which largely occurred in 1980 and 1990. This corresponds with Webb (1990) who reported a loss of 150 ha of heathland for roads, houses and factories between 1978 and 1987 and Rose et al. (2000) who reported a further loss of 100 ha 1987-1996.

Although Good surveyed the Dorset landscape evenly, with roughly 5-6 stands per square mile (Good 1937), it is possible that biases were introduced into the time series when particular sites were removed from the study (see Fig. 2). For instance, over 400 sites were eliminated from the north-west due to incomplete land cover map coverage in 1990, whilst sites which were less than 0.5 ha were also removed (Fig. 2). While it is not clear if eliminating these sites introduced any bias, one might expect the habitat 
losses to be underestimated in this study, given that smaller sites $(<0.5 \mathrm{ha})$, which are more vulnerable to loss, were not considered. For four of the six seminatural habitat types we found significant differences between the size of sites which remained and were lost between 1930 and 2015, but these patterns varied. For broadleaved woodland and calcareous grassland, lost sites were significantly larger than those which remained, but the opposite pattern was found for heathland and for fen, marsh and swamp (see Appendix 2 for further details).

\section{Land cover change in protected sites}

Sites which are protected through designation as a SSSI were more likely to remain unchanged compared to those which are not protected. Ridding et al. (2015) also found that $91 \%$ of protected English semi-natural grasslands persisted between 1960 and 2013, compared with only $27 \%$ in non-protected sites. While there has been controversy about the effectiveness of protected areas, they have proven valuable around the world at conserving habitat (Geldmann et al. 2013). The retention of neutral grassland in this study was not affected by protection status, which may be because the management of such grasslands has caused vegetation change. For instance, only $42 \%$ of neutral grasslands which are designated as SSSIs are considered to be in favourable condition, with under-grazing and abandonment being the main cause of decline (Williams 2006). Our study suggests that statutory protection is beneficial in preventing habitat loss through damaging activity, however appropriate management of protected sites is essential.

\section{Conclusions}

This study has confirmed a considerable decline in semi-natural habitats across the Dorset landscape between 1930 and 2015. This trend was non-linear for the majority of semi-natural habitats, with the greatest losses occurring between 1950 and 1980, and slowing after this time. This period coincides with the largest gains to arable and improved grassland, suggesting that these drivers did not necessarily lead to the loss of habitats immediately after the Second World War, as often presumed, but instead conversion to intensive land covers continued to increase until
1980. Although the loss of semi-natural habitats declined after this period, largely because there were very few sites left to convert, habitats were still being lost over the last 25 years. This suggests an urgent need both to protect remaining semi-natural habitats fully, which this study has shown to be effective, but also to restore these habitats to start to reverse the huge losses.

Acknowledgements The National Library of Scotland provided access to the Ordnance Survey maps. The Dorset Environmental Records Centre (DERC), particularly Carolyn Steele, assisted with the Good and Horsfall data, and Bryan Edwards and the Area of Outstanding Natural Beauty (AONB) team allowed access to the 1950s chalk grassland GIS layer. This work is funded by the Mechanisms and Consequences of Tipping Points in Lowland Agricultural Landscapes (TPAL; NE/P007716/1) project (www.tpalvaluing-nature.co.uk). The Valuing Nature Programme (www.valuing-nature.net.) is funded by the Natural Environment Research Council (NERC), the Economic and Social Research Council, the Biotechnology and Biological Sciences Research Council, the Arts and Humanities Research Council and the Department for Environment, Food and Rural Affairs. The recast LCM1990 was supported by the NERC award number NE/R016429/1 as part of the UK-SCAPE programme delivering National Capability.

Open Access This article is distributed under the terms of the Creative Commons Attribution 4.0 International License (http:// creativecommons.org/licenses/by/4.0/), which permits unrestricted use, distribution, and reproduction in any medium, provided you give appropriate credit to the original author(s) and the source, provide a link to the Creative Commons license, and indicate if changes were made.

\section{References}

AHDB (2018) Livestock and the arable rotation. Warwickshire Aldhous JR (1997) British forestry: 70 years of achievement. Forestry 70:

Barr CJ, Bunce RGH, Clarke RT, Fuller RM, Furse MT, Gillespie MK, Groom GB, Hallam CJ, Hornung M, Howard DC, Ness MJ (1993) Countryside Survey 1990: Main Report. Dep Environ 2

Bateman IJ, Harwood AR, Mace GM, Watson RT, Abson DJ, Andrews B, Binner A, Crowe A, Day BH, Dugdale S, Fezzi C, Foden J, Hadley D, Haines-Young R, Hulme M, Kontoleon A, Lovett AA, Munday P, Pascual U, Paterson J, Perino G, Sen A, Siriwardena G, van Soest D, Termansen M (2013) Bringing ecosystem services into economic decision-making: land use in the United Kingdom. Science 341:45-50

Bengtsson J, Bullock JM, Egoh B, Everson C, Everson T, O'Connor T, O'Farrell PJ, Smith HG, Lindborg R (2019) 
Grasslands-more important for ecosystem services than you might think. Ecosphere 10:e02582

Best R, Coppock J (1962) The changing use of land in Britain. McMillan, London

Bürgi M, Bieling C, von Hackwitz K, Kizos T, Lieskovský J, Martín MG, McCarthy S, Müller M, Palang H, Plieninger T, Printsmann A (2017) Processes and driving forces in changing cultural landscapes across Europe. Landsc Ecol 32:2097-2112

Bürgi M, Hersperger AM, Schneeberger N (2004) Driving forces of landscape change-current and new directions. Landsc Ecol 19:857-868

Burnham KP, Anderson DR (2002) Model selection and multimodel inference: a practical information-theoretic approach. Springer, New York

Campaign to Protect Rural England (2018) The State of the Green Belt. London

Carey PD, Wallis S, Chamberlain PM, Cooper A, Emmett BA, Maskell LC, McCann T, Murphy J, Norton LR, Reynolds B, Scott WA, Simpson IC, Smart SM, Ullyett JM (2008) Countryside survey: UK results from 2007. NERC/Centre for Ecol Hydrol, 105 pp

Coleman A (1979) Has planning fulfilled its aims? In: Land use perspectives. The Land Decade Educational Council, London, pp 20-33

Cordingley JE, Newton AC, Rose RJ, Clarke RT, Bullock JM (2015) Habitat fragmentation intensifies trade-offs between biodiversity and ecosystem services in a heathland ecosystem in Southern England. PLoS ONE. https://doi. org/10.1371/journal.pone.0130004

Dearing JA, Yang X, Dong X, Zhang E, Chen X, Langdon PG, Zhang K, Zhang W, Dawson TP (2012) Extending the timescale and range of ecosystem services through paleoenvironmental analyses, exemplified in the lower Yangtze basin. Proc Natl Acad Sci. https://doi.org/10.1073/pnas. 1118263109

DEFRA (2018) UK Biodiversity Indicators 2018. London

Diaz A, Keith SA, Bullock JM, Hooftman DAP, Newton AC (2013) Conservation implications of long-term changes detected in a lowland heath plant metacommunity. Biol Conserv 167:325-333

Diekmann M, Jandt U, Alard D, Bleeker A, Corcket E, Gowing DJG, Stevens CJ, Duprè C (2014) Long-term changes in calcareous grassland vegetation in North-western Germany-no decline in species richness, but a shift in species composition. Biol Conserv 172:170-179

Diemont WH, Degn HJ, Webb N (1996) A pan-European view on heathland conservation. In: Proceedings of the National Heathland Conference 1996, Peterborough

Dorset County Council (2018) Dorset Explorer. https://explorer. geowessex.com/. Accessed 4 Apr 2018

Drummond MA, Griffith GE, Auch RF, Stier MP, Taylor JL, Hester DJ, Riegle JL, McBeth JL (2017) Understanding recurrent land use processes and long-term transitions in the dynamic south-central United States, c. 1800 to 2006. Land Use Policy 68:345-354

Edwards B (2006) Changes in the area of downland and rough pasture on the Dorset chalk 1946-2006

European Environment Agency (2010) The European Environment State and Outlook 2010
European Environment Agency (2017) Landscapes in transition. Luxembourg

Fuller RM (1987) The changing extent and conservation interest of lowland grasslands in England and Wales: a review of grassland surveys 1930-1984. Biol Conserv 40:281-300

Fuller RM, Groom GB, Jones AR, Thomson AG (1993) Land Cover Map 1990 (25 m raster, GB)

Gaston KJ, Jackson SF, Nagy A, Cantú-Salazar L, Johnson M (2008) Protected areas in Europe. Ann N Y Acad Sci 1134:97-119

Geldmann J, Barnes M, Coad L, Craigie ID, Hockings M, Burgess ND (2013) Effectiveness of terrestrial protected areas in reducing habitat loss and population declines. Biol Conserv 161:230-238

Good R (1937) An account of a botanical survey of Dorset. Proc Linn Soc 149:114-116

Granadeiro JP, Andrade J, Palmeirim JM (2004) Modelling the distribution of shorebirds in estuarine areas using generalised additive models. J Sea Res 52:227-240

Green BH (1990) Agricultural intensification and the loss of habitat, species and amenity in British grasslands: a review of historical change and assessment of future prospects. Grass Forage Sci 45:365-372

Greve M, Chown SL, van Rensburg BJ, Dallimer M, Gaston KJ (2011) The ecological effectiveness of protected areas: a case study for South African birds. Anim Conserv 14:295-305

Hallmann CA, Sorg M, Jongejans E, Siepel H, Hofland N, Schwan H, Stenmans W, Müller A, Sumser H, Hörren T, Goulson D, De Kroon H (2017) More than 75 percent decline over 27 years in total flying insect biomass in protected areas. PLoS ONE. https://doi.org/10.1371/ journal.pone.0185809

Hambler C, Henderson PA, Speight MR (2011) Extinction rates, extinction-prone habitats, and indicator groups in Britain and at larger scales. Biol Conserv 144:713-721

Hill MO (1996) TABLEFIT, Version 10, for identification of vegetation types. Wallingford, Centre for Ecology and Hydrology

Hooftman DAP, Bullock JM (2012) Mapping to inform conservation: a case study of changes in semi-natural habitats and their connectivity over 70 years. Biol Conserv 145:30-38

Hooftman DAP, Edwards B, Bullock JM (2016) Reductions in connectivity and habitat quality drive local extinctions in a plant diversity hotspot. Ecography (Cop) 39:583-592

Horsfall A (1981) A pattern of change: observations on plant habitat change in North-East Dorset since 1931: Part 3, 1981. Dorset Proc 103

Isaac NJB, Brotherton PNM, Bullock JM, Gregory RD, Boehning-Gaese K, Connor B, Crick HQP, Freckleton RP, Gill JA, Hails RS, Hartikainen M, Hester AJ, MilnerGulland EJ, Oliver TH, Pearson RG, Sutherland WJ, Thomas CD, Travis JMJ, Turnbull LA, Willis K, Woodward G, Mace GM (2018) Defining and delivering resilient ecological networks: nature conservation in England. J Appl Ecol 55:2537-2543

Jackson DL (2000) Guidance on the interpretation of the Biodiversity Broad Habitat Classification (terrestrial and freshwater types): definitions and the relationship with other classifications. JNCC Report 307 
JNCC (2015) Guidelines for selection of biological SSSIs. http://jncc.defra.gov.uk/page-2303. Accessed 7 Apr 2015

Maskell LC, Smart SM, Bullock JM, Thompson KEN, Stevens CJ (2010) Nitrogen deposition causes widespread loss of species richness in British habitats. Glob Chang Biol 16:671-679

Mason WL (2007) Changes in the management of British forests between 1945 and 2000 and possible future trends. Ibis (Lond 1859) 149:41-52

Moore N (1962) The heaths of Dorset and their conservation. J Ecol 50:369-391

Nail S (2008) Forest policies and social change in England. Springer, New York

Natural England (2014) Sites of Special Scientific Interest and historical monuments. https://www.gov.uk/sites-ofspecial-scientific-interest-and-historical-monuments. Accessed 6 Jan 2018

NCC (1984) Nature conservation in Great Britain. Nature Conservancy Council, Peterborough

Newton AC, Walls RM, Golicher D, Keith SA, Diaz A, Bullock JM (2012) Structure, composition and dynamics of a calcareous grassland metacommunity over a 70-year interval. J Ecol 100:196-209

Ordnance Survey (1961) Ordnance Survey Great Britain 1:25,000, 1937-1961. Using: National Library of Scotland. http://maps.nls.uk/index.html. Accessed October 2017

Ordnance Survey (2017) 1:250,000 Scale Colour Raster. Crown copyright and database right 2017 OS 100017572. Accessed December 2017

Parry M, Hossell J, Wright L (1992) Land use in the United Kingdom. In: Whitby M (ed) Land use change: the causes and consequences. Institute of Terrestrial Ecology, pp 7-14

Piessens K, Hermy M (2006) Does the heathland flora in northwestern Belgium show an extinction debt? Biol Conserv 132:382-394

Pocock MJO, Roy HE, Preston CD, Roy DB (2015) The Biological Records Centre: a pioneer of citizen science. Biol J Linn Soc 115:475-493

Poschlod P, Wallis de Vries MF (2002) The historical and socioeconomic perspective of calcareous grasslands-lessons from the distant and recent past. Biol Conserv 104:361-376

Powney GD, Carvell C, Edwards M, Morris RKA, Roy HE, Woodcock BA, Isaac NJB (2019) Widespread losses of pollinating insects in Britain. Nat Commun. https://doi.org/ 10.1038/s41467-019-08974-9

Pretty J, Brett C, Gee D, Hine R, Mason C, Morison J, Raven H, Rayment M, van der Bijl G (2000) An assessment of the total external costs of UK agriculture. Agric Syst 65:113-136

Quine C, Cahalan C, Hester A, Humphrey J, Kirby K, Moffat A, Valatin G (2011) Woodlands. UK National Ecosystem Assessment Technical Report. UNEP-WCMC, Cambridge, pp 241-294

R Core Team (2017) R: a language and environment for statistical computing. R Foundation for Statistical Computing, Vienna

Reif J, Vermouzek Z (2019) Collapse of farmland bird populations in an Eastern European country following its EU accession. Conserv Lett 12:e12585
Renard D, Rhemtulla JM, Bennett EM (2015) Historical dynamics in ecosystem service bundles. Proc Natl Acad Sci USA 112:13411-13416

Ridding LE, Redhead JW, Pywell RF (2015) Fate of semi-natural grassland in England between 1960 and 2013: a test of national conservation policy. Glob Ecol Conserv 4:516-525

Rodwell JS (1992) British plant communities: grasslands and montane communities. Cambridge University Press, Cambridge

Rose RJ, Webb NR, Clarke RT, Traynor CH (2000) Changes on the heathlands in Dorset, England, between 1987 and 1996. Biol Conserv 93:117-125

Rowland CS, Morton R., Carrasco L, McShane G, O'Neil AW, Wood CM (2017a) Land Cover Map 2015 (vector, GB)

Rowland CS, Morton RD, Carrasco L, O'Neil A (2017b) Applying Earth Observation to assess UK land use change: Lot 2 Medium Resolution Optical, Report to BEIS, London

Sang A, Teder T, Helm A, Pärtel M (2010) Indirect evidence for an extinction debt of grassland butterflies half century after habitat loss. Biol Conserv 143:1405-1413

Secretariat of the Convention on Biological Diversity (2014) Global Biodiversity Outlook 4. Montréal

Soga M, Gaston KJ (2018) Shifting baseline syndrome: causes, consequences, and implications. Front Ecol Environ 16:222-230

Song X, Hansen MC, Stehman SV, Potapov PV, Tyukavina A, Vermote EF, Townshend JR (2018) Global land change from 1982 to 2016. Nature 560:639-643

Stamp D (1931) The land utilisation survey of Britain. Geogr J 78:40-47

Steffen W, Broadgate W, Deutsch L, Gaffney O, Ludwig C (2015) The trajectory of the anthropocene: the great acceleration. Anthr Rev. https://doi.org/10.1177/ 2053019614564785

Steffen W, Crutzen PJ, McNeill JR (2007) The anthropocene: are humans now overwhelming the great forces of nature. Ambio 36:614-621

Swetnam RD (2007) Rural land use in England and Wales between 1930 and 1998: mapping trajectories of change with a high resolution spatio-temporal dataset. Landsc Urban Plan 81:91-103

Tittensor DP, Walpole M, Hill SLL, Boyce DG, Britten GL, Burgess ND, Butchart SHM, Leadley PW, Regan EC, Alkemade R, Baumung R, Bellard C, Bouwman L, Bowles-Newark NJ, Chenery AM, Cheung WWL, Christensen V, Cooper HD, Crowther AR, Dixon MJR, Galli A, Gaveau V, Gregory RD, Gutierrez NL, Hirsch TL, Höft R, Januchowski-Hartley S, Karmann M, Krug CB, Leverington FJ, Loh J, Lojenga RK, Malsch K, Marques A, Morgan DHW, Mumby PJ, Newbold T, Noonan-Mooney K, Pagad SN, Parks BC, Pereira HM, Robertson T, Rondinini C, Santini L, Scharlemann JPW, Schindler S, Sumaila UR, Teh LSL, van Kolck J, Visconti P, Ye Y (2014) A mid-term analysis of progress toward international biodiversity targets. Science 346:241-244

Van der Sluis T, Pedroli B, Frederiksen P, Kristensen SBP, Busck AG, Pavlis V, Cosor GL (2019) The impact of European landscape transitions on the provision of landscape services: an explorative study using six cases of rural land change. Landsc Ecol 34:307-323 
van Dijk G (1991) The status of semi-natural grasslands in Europe. In: Goriup PD, Batten LA, Norton JA (eds) The conservation of lowland dry grassland birds in Europe. Joint Nature Conservation Committee, Peterborough, pp 15-36

van Swaay C, van Strien A, Harpke A, Fontaine B, Stefanescu C, Roy D, Maes D, Kühn E, Õunap E, Regan E and Švitra G (2013) The European Grassland Butterfly Indicator: 1990-2011. European Environment Agency Technical Reports

Watson R, Albon S (2011) UK National Ecosystem Assessment: synthesis of the key findings. UNEP-WCMC, Cambridge

Watson SCL, Grandfield FGC, Herbert RJH, Newton AC (2018) Detecting ecological thresholds and tipping points in the natural capital assets of a protected coastal ecosystem. Estuar Coast Shelf Sci 215:112-123

Webb NR (1990) Changes on the heathlands of Dorset, England, between 1978 and 1987. Biol Conserv 51:273-286
Webb JR, Drewitt AL, Measures GH (2010) Managing for species: Integrating the needs of England's priority species into habitat management. Part 1 Report. Sheffield

Webb NR, Haskins LE (1980) An ecological survey of heathlands in the Poole basin, Dorset, England, in 1978. Biol Conserv 17:281-296

Williams J (2006) Common standards monitoring for designated sites: first six year report. Joint Nature Conservation Committee, Peterborough

Wood S (2017) Generalized additive models: an introduction with R, wnd edn. Boca Raton, Chapman and Hall/CRC

Zayed Y (2016) Agriculture: historical statistics. Routledge, London

Zhang XQ (2016) The trends, promises and challenges of urbanisation in the world. Habitat Int 54:241-252

Publisher's Note Springer Nature remains neutral with regard to jurisdictional claims in published maps and institutional affiliations. 